\title{
Research Approaches «Memory Studies» In the Study of Reverse Socio-Cultural Processes in Modern Russian Society
}

\author{
Tatiana V. Pushkareva' \& Darya V. Agaltsova ${ }^{2}$ \\ ${ }^{1}$ Candidate of Philosophy, Associate Professor of the Department of Visual communication \\ Synergy University, Moscow, Russia. E-mail: ap-bib@yandex.ru \\ ${ }^{2}$ Candidate of Pedagogy, Associate Professor of English Language Training and Professional \\ Communication Department, Financial University under the Government of the Russian \\ Federation, Moscow, Russia. E-mail: darya_agaltsova@mail.ru
}

\begin{abstract}
Reverse processes in the public socio-cultural life of modern Russia are associated with the revival of a number of contradictory past values: the Soviet society ideals (the social experiment of building socialism ended twenty years ago, and before that it lasted more than 70 years); religious Orthodox revival (focused on the values of pre-revolutionary Russia before 1917); the development of traditional folk culture (transferring the value horizon into pre-Christian Slavic culture). The purpose of the article is to show how historical memory "lives" in the collective consciousness of modern Russians, how the archaization processes of historical memory and memorial practices are implemented at various social levels - from individual families (family memory), lower social cells (the level of municipalities, local clubs, schools), to federal school textbooks and national holidays. And turning to the analysis of Russian reality through the approaches of "memory studies" can have serious heuristic potential.
\end{abstract}

Keywords: cultural memory, historical memory, archaic, tradition, Soviet past, Russia.

\section{Introduction}

The globalization processes from inception to the present day manifest themselves ambivalently in the economic and socio-cultural area: centripetal tendencies are inevitably accompanied by centrifugal ones, the unfolding processes of modernization are inextricably linked with the revival of seemingly long-gone economic, social, and cultural phenomena. Russian society in these processes over the past twenty years has turned into space where the "shadow side" of globalization and modernization, namely, the archaization of social and cultural life has become mainstream.

At the same time, a deep connection is revealed between the processes of reanimation of the economic and social archaic (pre-market economic relations) (Semyonov, 2oo; Nikolaeva, 2005), growing in Russian society, on the one hand, and the increasing processes in the sociocultural role of the past, history and historical memory, the remythologization of public consciousness - from the other hand (Nikolaeva, Pushkareva, \& Shemyakina, 2015).

(C) AesthetixMS 2020. This Open Access article is published under a Creative Commons Attribution Non-Commercial 4.0 International License (http://creativecommons.org/licenses/by-nc/4.0/), which permits non-commercial re-use, distribution, and reproduction in any medium, provided the original work is properly cited. For citation use the DOI. For commercial re-use, please contact editor@rupkatha.com. 
The complexity of the study of reversible processes in the socio-cultural sphere is that the answer to the question is not always obvious: we are dealing with an appeal to a cultural tradition - a universal basis for the development of cultural innovation, or we are talking about an archaic that turns out to be totally closed on itself, and it does not imply development and ultimately leads to stagnation. A kind of heuristic key to solving this problem can be the direction of modern humanities - memory studies.

\section{Memory boom»: epistemological and social prerequisites}

"Memory studies" formation as a research paradigm is associated with the names of Maurice Halbwachs, Emil Durkheim, Pitirim Sorokin, Robert Merton and other researchers. In the classical works "memory studies" was the cultural reference point of historical time, shown culturally-meaningful ways to synchronize life groups, family was considered as the presenter of cultural memory, but all this happened in a purely academic manner. Since the end of the 2oth century, all these academic topics have quite unexpectedly acquired a pronounced social significance.

The social prerequisite for the "memory studies" activation can be considered the events of the 1980s-9os, when about a dozen new states were formed on the territory of post-Soviet Europe and Russia, which had to re-form the state ideology and, in this regard, "rewrite history", as well as solve the problem cultural, political identification of large national groups. This sharply actualized the national dimension of historical memory and led to a whole series of "wars of memory".

Simultaneously with this, there were processes of comprehension and rethinking of the lessons of the Second World War in the countries of Western Europe, the formation of international human rights institutions. The logic of the economic and political integration of the European Union demanded and continues to demand the cultural and ideological formation of a new Europe, which is reflected in attempts to construct a supranational version of historical memory.

The epistemological prerequisite is associated with a certain theoretical turn in the study of nations and nationalism that took place in the 8 os of the last century. This turn was in part due to the release of Benedict Anderson's now classic "Imagined Communities" (1983) (Megill, 2007). Anderson speaks about the value, cultural, rootedness of "imagined communities", reveals the mechanisms of creation ("imagination") of nations on the basis of concrete historical material using the example of the development of the census, map and museum in Southeast Asia, develops the concept of "national consciousness" (Anderson, 2001). We can say that Anderson interprets the nation as a universal useful illusion, without which the existence of a person in a secularized world is impossible.

As A. Megill notes, the most characteristic feature of modern life is the lack of stability at the identity level, which leads to the project of constructing memory in order to construct the identity itself (Megill, 2007). And here the idea of Anderson's "imagined communities" are more relevant than the ideas of Halbwachs, who believed that social identity arises even before the collective memories that they design. Collective memories only give a new form to the identity that built them, but identity always precedes memory.

The system-forming concept for "memory studies" was the concept of "memory places" by

Pierre Nora. The surge of attention to the problems of historical memory is closely related to the 
work and creativity of Pierre Nora (born in 1931), who is now the head of the "new historical school" (this is the modern name of the school of Annals). In 1984, in connection with the celebration of the anniversary of the great French revolution, on the initiative and under the general editorship of Pierre Nora, the publication of the seven-volume book "Places of memory" (Nora at al, 1999) began, which catalogued monuments, ideas, symbols, texts, and holidays associated with the identity of the French nation.

After French scientists with similar projects were the Dutch, Italians and Germans, in 2008 Russian "places of memory" were also published in French (author: famous Swiss slavist Georges Niva) (Nivat, 2007, 2019).

The baton in the research of historical memory initiated by French humanitarians was taken over by Jan and Aleida Assmann - professors at the University of Constance, Germany, who develop this problem on the material of ancient cultures and modern society in Germany. Thus, the most extensive attempt to theoretically substantiate the use of the concept of "collective memory" in historical, philosophical and sociological research is associated with the works of Aleida Assmann (Assman, 2014).

For European memory studies, the "culture of historical memory" neologism has recently become very important. In Assmann's works, "culture of historical memory" refers to the new political culture of Europe, the formation of which is conditioned by the requirements of globalization (and, in particular, the formation of the EU). The distinctive features of this new political culture, according to the author, are the expressed ethical dimension (based on the ideas of human rights) and the inclusive nature of historical memory, focused primarily on creating a coherent supranational version of the tragedy of the Second World War.

Thus, A. Assmann's theory of historical memory is closely connected with the politics of memory, with the ideology of modern democratic societies. It is no exaggeration to say that memory studies in the interpretation of Aleida Assmann acts as a kind of response to a certain social order, which once again encourages humanitarians to reflect on the actual problem of the social conditionality of scientific knowledge.

\section{Peculiarities of Russian cultural memory}

The cultural memory of Russian society remains a "minefield" of hidden narratives, meanings, values, repressed emotions and psychomotor reactions. This fragment of socio-cultural reality influences on the performed social actions and acts as a cultural determinant of modern society, practically unaware of the actors themselves, and escaping from the researcher's gaze. The rigid tightness of the functioning of informal (oral) and official (written) discourses in Russian society aggravates this situation.

One of the main reasons for the fact that "the recent past persistently returns to Russian politics and culture" according to the A. Etkind's opinion is the incompleteness of the public understanding process, the lack of an unambiguous legal and ethical assessment of the Stalinist terror (30s of the XX century) and the system of state Soviet violence in general (Etkind, 2018, 21). Three waves of de-stalinization, initiated by the heads of state $(1956,1985,2010)$ and finding each time a great response in public life, remained incomplete and eventually turned into another return to the idealization of the Soviet past. In addition, the inconsistency of de-stalinization leads to the fact that the Soviet trauma of trampling on humanity is hidden, reflects in modern Russian culture, and the range of social and cultural consequences of this is very wide (from 
necrophilic literary phantasmagoria to problems of moral decomposition, difficulties in distinguishing between good and evil, deconstruction of the value horizon). "The present is oversaturated with the past, and this solution does not settle and does not precipitate," writes A. Etkind, describing the social life of modern Russia (Etkind, 2018, 22).

The intoxication with the history and the past is also connected with the fact that the Soviet project of a new state and a new person creating is connected with a total break with the past both at the state level and at the level of each family. Repression based on the principle of social origin forced parents to conceal real information about their ancestors, and knowledge of their family history could be dangerous. "The famous iron curtain separated us not only from abroad, but from our own history" (Sedakova, 2017). Therefore, today's intoxication with the past has become in many ways a kind of compensation for this fundamental break with the "old world", which lasted for more than seventy years.

\section{Theoretical matrix for studying reverse processes}

To study the diverse manifestations of reverse processes in modern Russia, we propose a theoretical matrix based on the memory studies approach, which can help to identify and systematize the facts of socio-cultural life based on the analysis of "places of memory" at different levels.

Reverse socio-cultural processes are considered here in a combination of various manifestations - both conscious appeal to significant facts and practices of the past ("revival"), and an attempt to restore erroneous/dead-end socio-cultural experience ("reanimation"). The criterion for distinguishing the first type of reverse processes (revival of traditions) is the focus on upholding the unconditional value of human life and inclusion - the inclusion of cultural experience and associated memories and memory places in a coherent picture that can become the basis for peaceful coexistence of groups. The criterion for distinguishing the second type of reverse processes (reanimation of erroneous cultural experience/its form) is the focus on exclusivity - the defense of uniqueness and opposition of groups to each other.

Inclusion and exclusion categories for understanding the process of creating a coherent civil version of history and ways to translate it are developed in the German cultural and didactic tradition (definitions of A. Assmann). We can say that the model of inclusive historical memory is based on the binary opposition of "I" and "Other", while the model of exclusive historical memory is based on the opposition of "I" and "someone Else". The model of inclusive historical memory is characterized by the desire to include and integrate the memories of different groups of participants in historical events in a single, but diverse, coordinated version of the past, which is aimed at peaceful coexistence and minimizing conflicts in supranational entities. Until recently, Russian didactics saw as a priority task "the search for an optimal balance of domestic and international experience in building a system of historical education", as well as" to ensure an optimal balance for Russian society between universal world values and national and cultural identity" (Vyazemsky \& Strelova, 2003, 6-7).

Followers of the inclusive historical memory model in political culture and education call for "removing" past conflicts between countries and nations through mutual apologies, joint rituals of remembrance of the dead, and common holidays. The exclusive historical memory model assumes the existence of insurmountable contradictions between the participants of past conflicts, which makes it fundamentally impossible to integrate historical memory in the present. In the context of global economic and cultural development, the inclusiveness of historical 
consciousness and historical and cultural memory is considered by German specialists of "memory studies" as a condition not only for successful international cooperation, but also an important condition for social stability, security of society and human existence.

Matrix of systematization of reverse socio-cultural processes facts in modern Russia

\begin{tabular}{|c|c|c|c|}
\hline & Soviet past & $\begin{array}{c}\text { Pre-Revolutionary } \\
\text { Russia }\end{array}$ & $\begin{array}{l}\text { Traditional pre- } \\
\text { Christian culture }\end{array}$ \\
\hline Family & $\begin{array}{l}\text { Denis Karagodin's } \\
\text { case }\end{array}$ & "Genealogical boom" & Ethnopedagogy \\
\hline Mid-level social cells & "Sabbatarian" & $\begin{array}{l}\text { Development of } \\
\text { religious community } \\
\text { life }\end{array}$ & Neo-paganism \\
\hline State & $\begin{array}{l}\text { Separate teaching of } \\
\text { Russian and foreign } \\
\text { history } \\
\text { "Jugaphilia" (Love for } \\
\text { Stalin) }\end{array}$ & $\begin{array}{l}\text { Modular temples } \\
\text { project in Moscow } \\
\text { «July, } 28 \text { - the day of } \\
\text { the Epiphany of } \\
\text { Russia» }\end{array}$ & "Traditional values" \\
\hline
\end{tabular}

A detailed analysis can be performed for each cell of this matrix. Here is an analysis of one example: reverse practice in teaching history at school (State/Soviet past).

The problem of teaching history in secondary schools has never been of didactic nature, it is always closely connected with state policy (Ferro, 1992), with the global historical and cultural orientations of states and their associations, the choice of certain socio-cultural worldview models in different communities (Alayan, 2010), as well as with the solution of the quite utilitarian question of what and how "to remember" in order to live in a better present and future (Misztal, 2010).

The material for the analysis of modern Russian historical didactics is educational standards, curriculum, teaching kits, works of leading experts in the field of historical didactics, written and oral statements of leading Russian history teachers. In Russian schools, two subjects are taught in parallel-foreign history and the history of the Fatherland, in different regions of the Russian Federation there is supplemented by the study of regional history with their own textbooks and manuals. Even Mark Ferro in his classic work, criticizing the Soviet historical education, could not fail to note its systematic nature, which allowed Soviet teachers to devote more time and attention to the study of the history of "other" people than their colleagues abroad (Ferro, 1992, 170). The same feature in the modern globalizing world can be assessed as a kind of factor in promoting isolationism. In Russian textbooks, the statist line is more visible. In Russia, world, national and regional history are taught as separate disciplines and are accompanied by their own textbooks and manuals. The structure of teaching history that has developed in the Russian school is rather focused on the formation of an exclusive historical memory. The discussion of limiting the variability of educational book publishing in the segment of national history textbooks strengthens this traditional orientation of school historical education to the formation of exclusive historical memory, while at the same time leaving a reserve for the 
development of inclusive historical memory in school courses of foreign and regional history (Pushkareva, 2014).

The analysis of one example from our matrix of reverse socio-cultural processes shows the complexity and ambiguity of each fact of society's appeal to the past, which makes us wonder in each individual case whether it is tradition or archaic.

\section{Conclusion}

The use of "memory studies" approaches for studying reverse socio-cultural processes in modern Russia can be carried out as follows.

Reverse socio-cultural processes are clearly recorded in "memory places", understood in the broad sense (not only as places, but as practices, art works, etc.).

The correlation of "memory places" with certain value horizons and different levels of social functioning becomes the basis for building a theoretical matrix that allows cataloging, generalizing, and systematizing various reverse socio-cultural processes.

In the future, the developed matrix will allow using quantitative analysis. The use of the concepts "memory studies" "inclusive historical memory" and "exclusive historical memory" (A. Assmann) allows us to distinguish between archaic and tradition within the reverse socio-cultural processes.

The archaization phenomenon of modern Russian society is a relevant scientific object, the study of which is not only of national importance, but can reveal the universal mechanisms of interaction between progressive and reversible, tradition and innovation, memory and oblivion in socio-cultural development.

\section{Funding Disclosure/Acknowledgement}

The article is a part of the Society of Professional Sociologists' research programs, supported by the Russian Fund for Basic Research. Research project RFBR № 19-011-00943 "Forward to the past: archaism and archaization trends in contemporary Russian society (interdisciplinary analysis)" (2019-2021).

\section{References}

Alayan, S. (Ed.). (2010). Education Reforms in the middle East: "I" and "others" in the school curriculum. Amman: Gift Alshorouk.

Anderson, B. (2001). Imagined communities. Moscow: Kanon-Press-C.

Assman, A. (2014). The Long shadow of the past: memorial culture and historical politics. Moscow: Boris Khlebnikov.

Etkind, A. (2018). Warped Mourning. Stories of the Undead in the Land of Unbured. Moscow: New literary review.

Ferro, M. (1992). How to tell a story to children in different countries of the world. Moscow: Higher school.

Megill, A. (2007). Historical epistemology, Moscow: Kanon+. 
7 Nivat, G. (Ed). (2007). Les sites de la mémoire russe, tome 1: Géographie de la mémoire russe.

Paris: Fayard.

Misztal, B. A. (2010). Collective memory in the era of globalization. Learning how and what to remember. Current sociology, 58, 1, 24-43.

Nikolaeva, U. G. (2005). Economic archaic and modernity. Moscow.: Dashkov and K.

Nikolaeva, U. G., Pushkareva T. V., \& Shemyakina E. M. (2015). The temporality of economic and sociocultural processes: the prospect of interdisciplinary analysis. Questions of cultural studies. Moscow, 9, 26-31.

Nivat, G. (Ed). (2007). Les sites de la mémoire russe, tome 1: Géographie de la mémoire russe. Paris: Fayard.

Nivat, G. (Ed). (2019). Les sites de la mémoire russe, tome 2: Histoire et mythes de la mémoire russe. Paris: Fayard.

Nora, P., Ozuf, M., Puimeg, G., Vinok, M., \& Hapaeva D. (1999). France-Memory. Sankt-Peterburg: St. Petersburg University Press.

Pushkareva, T. V. (2014). Historical didactics in Russia and Germany: coordinates of humanitarian dialogue. Historical, philosophical, political and legal sciences, cultural studies and art history. Questions of theory and practice. Tambov: Gramota, 4 (42), I, 149-151.

Sedakova, O. (2017). The work of grief. About the living and the unburied. The work of memory versus the work of life: the curse of the dead and the society of the living. Retrieved from: http://gefter.ru/archive/21713

Semyonov, Yu. I. (2003). Philosophy of history. Moscow: Contemporary notes.

Vyazemsky, E. E., Strelova, O. Yu. (2003). Theory and methodology of teaching history. Moscow: Vlados.

Tatiana V. Pushkareva, Candidate of Philosophy, Associate Professor of the Department of Visual Communication Synergy University Russia, Moscow. In 1994 graduated from the Historical Faculty of the Moscow State Pedagogical University. In 2001 defended the Candidate dissertation on the topic of «History-culture-memory: concerning the problem of historical time». Research internships at the universities in Germany and Spain. Since 1999 to 2020 taught at the Russian State Social University. Research interests: memory studies, modern culture, modern society, temporality, visual culture. Author of more than 100 scientific works.

Darya V. Agaltsova, Candidate of Pedagogy, Associate Professor of English Language Training and Professional Communication Department, Financial University, Moscow, Russia. In 2002 graduated from the Computer Science Faculty of Omsk State Pedagogical University (Specialty: Teacher of Computer science and English language). Since 2019 teaches at the Financial University under the Government of the Russian Federation. Research interests: new information technologies in education, modern society, English as a foreign language. 